\title{
Microbial production of auxin indole-3-acetic acid in marine sediments
}

\author{
A. Maruyama*, M. Maeda, U. Simidu \\ Ocean Research Institute, University of Tokyo, 1-15-1, Minamidai, Nakano, Tokyo 164, Japan
}

\begin{abstract}
Auxin indole-3-acetic acid (IAA) was detected in marine sediments for the first time using HPLC and immunological identification methods. The IAA content of the interstitial water in sediments varied, in the order of $10^{-10}$ to $10^{-6} \mathrm{~mol} \mathrm{l}^{-1}$, with sampling season and location. The content in seawater was much lower than that of sediments, ca $10^{-11}$ to $10^{-10} \mathrm{~mol} \mathrm{1^{-1 }}$ Considerable amounts of IAA were produced by various marine bacteria in vitro, especially in the presence of tryptophan. IAA production and accumulation was also enhanced when glucose, tryptophan and natural seaweed substrates were added to sediments and incubated under both aerobic and anaerobic conditions in the dark, which suggests that the natural microbial community contributes to IAA production in sediments. The amount of IAA that accumulated in the water surrounding sediments reached $10^{-7} \mathrm{~mol} \mathrm{l}^{-1}$ in the presence of seaweed substrate, and corresponded to the level in glucose plus tryptophan. Auxin-active compounds produced during microbial decay of natural organic materials may affect algal growth in natural environments.
\end{abstract}

\section{INTRODUCTION}

Auxin-and cytokinin-like plant hormonal compounds have been detected in natural seawater (Bentley 1960 , Pedersén \& Fridborg 1972, Kentzer et al. 1980). Using gas chromatography-mass spectrometric analysis, Pedersén (1973) identified a major cytokinin-active compound in seawater filtrates as 6-(3-methyl(-2-butenylamine) purine (isopentenyladenine). Since plant hormones are present in various marine algae, multicellular (Abe et al. 1972, Tay et al. 1985, 1987, Hofman et al. 1986, Mooney \& Van Staden 1987), unicellular (Grotbeck \& Vance 1972) and natural planktonic organisms (Bentley 1960), it is possible that plant hormones in seawater originate from algal plants (Pedersén 1973, Kentzer et al. 1980).

Recently we found that many bacterial strains isolated from seawater and sediments were able to produce cytokinin-active compounds under culture condition (Maruyama et al. 1986). Furthermore, we identified one of the cytokinin-active compounds from marine bacteria as isopentenyladenine (Maruyama et

\footnotetext{
- Present address: Fermentation Research Institute, Agency of Industrial Science and Technology, 1-1-3. Higashi, Tsukuba, Ibaraki 305, Japan
}

al. 1988), the same compound reported as a major cytokinin in seawater (Pedersén 1973). These findings allowed us to postulate on the microbial origin of cytokinins in marine environments. In addition, Mishra \& Kefford (1969) previously reported auxin-like effects of coral-sand (rich in microorganisms) on the growth of the multicellular green alga Caulerpa sertularioides suggesting that marine sediments probably contain certain auxin compounds or auxin-producing microorganisms. However, there has been no report on the presence of auxins or their producers in marine sediments.

In this paper, we try to demonstrate that microbial production of auxin indole-3-acetic acid (IAA) occurs in marine sediments. HPLC and enzyme-linked immunosolvent assay are used to identify and quantify IAA in seawater, sediment and bacterial culture samples. Tryptophan, which is known as a common precursor in IAA synthetic pathways among terrestrial plants and bacteria, was used to evaluate its effect on IAA production in both marine bacterial monoculture and fresh sediment culture. In addition, IAA production and accumulation in marine sediments is confirmed using a seaweed (predominant in the surrounding environment) as a possible substrate for sedimentary microorganisms. 


\section{MATERIAL AND METHODS}

Seawater and sediment samples. Locations of sampling areas are illustrated in Fig. 1. Samples of seawater and sediments were collected in Aburatsubo Inlet, Kanagawa Prefecture, Japan, from 1984 to 1985 and in Tokyo and Sagami Bays during the KT-87-2 cruise on board the R V 'Tansei-maru' (Ocean Research Institute, University of Tokyo) in March 1987. Sediments from the center of Tokyo Bay were black, muddy, and smelled of hydrogen sulfide, indicative of highly anaerobic conditions. Seawater samples were taken using a Van-Dorn sampler, and sediment with an Ekman-Birge sampler in Aburatsubo Inlet and with a box-corer in Tokyo and Sagami Bays. The seawater thus collected was immediately filtered through a glass fiber filter (Whatman $\mathrm{GF} / \mathrm{F}$ ) and the filtrate stored at $-20^{\circ} \mathrm{C}$. The upper 0 to $5 \mathrm{~cm}$ layer of sediment samples was also kept at $-20^{\circ} \mathrm{C}$ prior to use. In the laboratory, the thawed sediment sample was centrifuged at $10000 \times g$ for $30 \mathrm{~min}$ at $4^{\circ} \mathrm{C}$ and the supernatant used in IAA analysis.

Bacterial culture. Ten marine bacterial strains and 4 type-strains were used (Table 3). Three types of basal media were prepared, 1 defined medium (A) and 2 undefined media ( $\mathrm{B}$ and $\mathrm{C}$ ). Medium $\mathrm{A}$ contained glucose $(5 \mathrm{~g}), \mathrm{NH}_{4} \mathrm{Cl}(0.2 \mathrm{~g}), \mathrm{K}_{2} \mathrm{HPO}_{4}(7 \mathrm{mg})$, and Fe-EDTA (iron-ethylenediaminetetraacetate, $4 \mathrm{~g}$ ) in 11 of artificial seawater (ASW): $\mathrm{NaCl}(17.6 \mathrm{~g}), \mathrm{MgCl}_{2} \cdot 6 \mathrm{H}_{2} \mathrm{O}(8.0 \mathrm{~g})$, $\mathrm{Na}_{2} \mathrm{SO}_{4}(2.9 \mathrm{~g}), \mathrm{CaCl}_{2} \cdot 2 \mathrm{H}_{2} \mathrm{O}(1.1 \mathrm{~g}), \mathrm{KCl}(0.5 \mathrm{~g})$, tris(hydroxymethyl)-aminomethan $(9.1 \mathrm{~g})$, at $\mathrm{pH}$ 7.8. Medium $\mathrm{B}$ contained glucose $(2 \mathrm{~g})$, trypticase peptone $(\mathrm{BBL} ; 2 \mathrm{~g})$

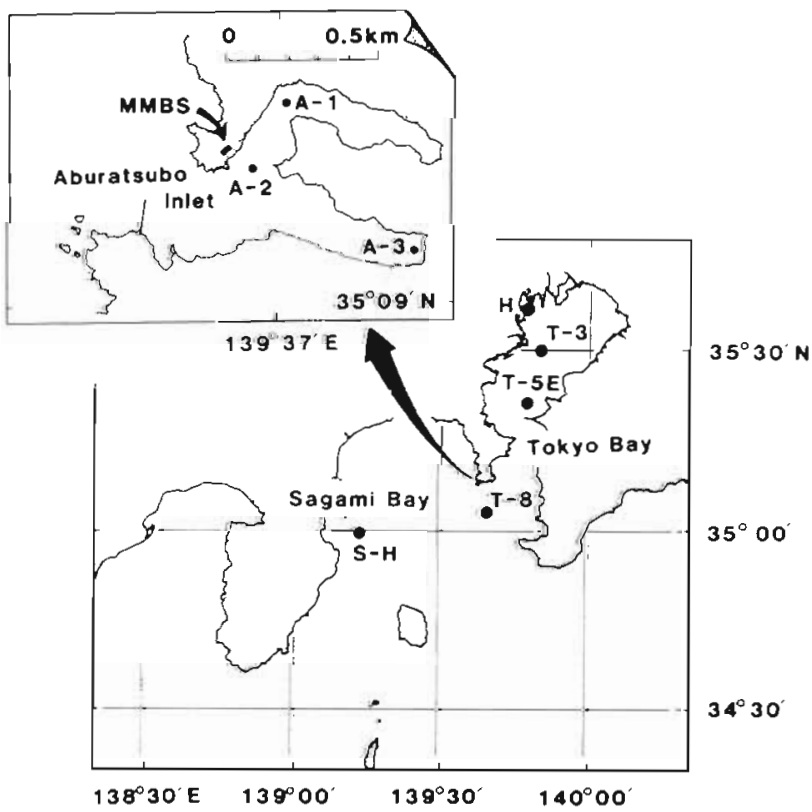

Fig. 1. Location of sampling stations. MMBS: Misaki Marine Biological Station, University of Tokyo and Bacto-Yeast extract (Difco; $1 \mathrm{~g}$ ) in $1 \mathrm{l}$ ASW; and Medium C had a composition of trypticase peptone $(4 \mathrm{~g})$ and Bacto-Yeast extract (1 g) in $11 \mathrm{ASW}$. Tryptophan was added at a concentration of $100 \mathrm{mg} \mathrm{l}^{-1}$. Bacteria were cultured in $50 \mathrm{ml} \mathrm{L}$-shape tubes containing $10 \mathrm{ml}$ of medium at $20^{\circ} \mathrm{C}$ on a reciprocal shaker and harvested at late-log phase by centrifugation at $11000 \times g$ for $20 \mathrm{~min}$ at $4^{\circ} \mathrm{C}$ - the supernatant was then used.

Incubation of sediment samples. Two sediment samples were collected in August, 1987 from Stns A-2 and A-3 in Aburatsubo Inlet (Fig. 1). Immediately after collection, each fresh sediment sample was divided into a total of 8 subsamples of $300 \mathrm{~cm}^{3}$ and stored in four $3 \mathrm{l}$ flasks and in four $500 \mathrm{ml}$ flasks. Sterilized ASW $(300 \mathrm{ml})$ was added to each and the flasks mixed. Among the 4 flasks prepared from 1 sediment sample, 3 were supplemented with either glucose $(0.6 \mathrm{~g})$, glucose $(0.6 \mathrm{~g})$ plus tryptophan $(6$ mg) or a green alga Ulva sp. (10 g wet wt); the remaining flask acting as control. These were then incubated for $7 \mathrm{~d}$ on a rotary shaker (at $200 \mathrm{rpm}$, eccentricity $=7 \mathrm{~cm}$ ). The other 4 (smaller) flasks were incubated for the same period, but without aeration. All subsamples were incubated in the dark at $20^{\circ} \mathrm{C}$. After incubation, the sedimentwater mixture of shaken samples was centrifuged at $10000 \times g$ for $30 \mathrm{~min}$ and the supernatant used in IAA analysis. For non-shaken flasks (i.e., unaerated), the water fraction above sediments was collected by decantation and filtered by Millipore GS-type filters (pore size $0.22 \mu \mathrm{m}$ ) and the filtrate used in IAA analysis. The remaining sediment was then centrifuged at $10000 \times g$ for $30 \mathrm{~min}$ and the supernatant also used for analysis. The green alga (used as a culture substrate) was collected from the surrounding littoral zone of the Inlet near the Misaki Marine Biological Station, University of Tokyo (Fig. 1). To estimate its original IAA content, a sample was extracted 3 times with $80 \%$ methanol at below $4{ }^{\circ} \mathrm{C}$. This extract was then filtered using a Toyo No. 3 paper filter and the IAA content of the filtrate determined.

Extraction and identification of IAA All samples were subjected to the following series of extractions for IAA. Each subsample was partitioned twice against diethyl ether at $\mathrm{pH} 8.5$ to 9.0. The aqueous phase was then ddjusted to $\mathrm{pH} 2.5$ to 3.0 and partitioned twice against diethyl ether. The acid-ether phases were combined and evaporated under vacuum at $40^{\circ} \mathrm{C}$, and the dried sample was then dissolved in distilled water. This extract was immediately applied to an HPLC using a Senshu Pak ODS-1251-N column $(4.6 \times 250 \mathrm{~mm})$ packed with $5 \mathrm{um}$ octadesylsilica gel (Nargel, FRG) in a Jasco Tri Rotar-VI HPLC system equiped with a Hitachi F-1000 fluorescent spectrophotometer (with an excitation at $280 \mathrm{~nm}$ and an emission at $350 \mathrm{~nm}$ ). IAA peak was determined by comparison to a retention time of authentic IAA (Wako), and the content calculated from the peak area using a chromatogram integrator (DPL-225, Jasco). Samples 
were eluted (in duplicate) at a flow rate of $1 \mathrm{ml} \mathrm{min}^{-1}$ with an isometrical condition of $25 \% \mathrm{CH}_{3} \mathrm{CN}$ in $50 \mathrm{mM}$ $\mathrm{CH}_{3} \mathrm{COOH}$. For accurate determination of IAA from marine sediments and bacterial cultures, every $0.5 \mathrm{ml}$ fraction eluted from HPLC was methylated by treatment with excess amounts of ethereal diazomethan (Schlenk \& Gellerman 1960) and then subjected to ELISA (enzymelinked immunosolvent assay) using the monoclonal antibody for IAA methylester as described by Mertens et al. (1985). Polystyrene flat-bottom microtitration plates (Nunc), precoated with rabbit anti-mouse immunoglobulin (Miles, Israel), were used. Monoclonal antibody for IAA methylester and alkaline phosphatase-labeled IAA methylester (Idetek, USA) were applied to the immunoassay according to the instructions. Each sample was assayed in duplicate and the authentic IAA methylester (Fluka) subjected to calibration at every assay.

\section{RESULTS}

\section{IAA in seawater and sediments}

The presence of IAA in sediment samples was comfirmed by HPLC-ELISA analysis. A fluorescent compound with a retention time identical to authentic IAA

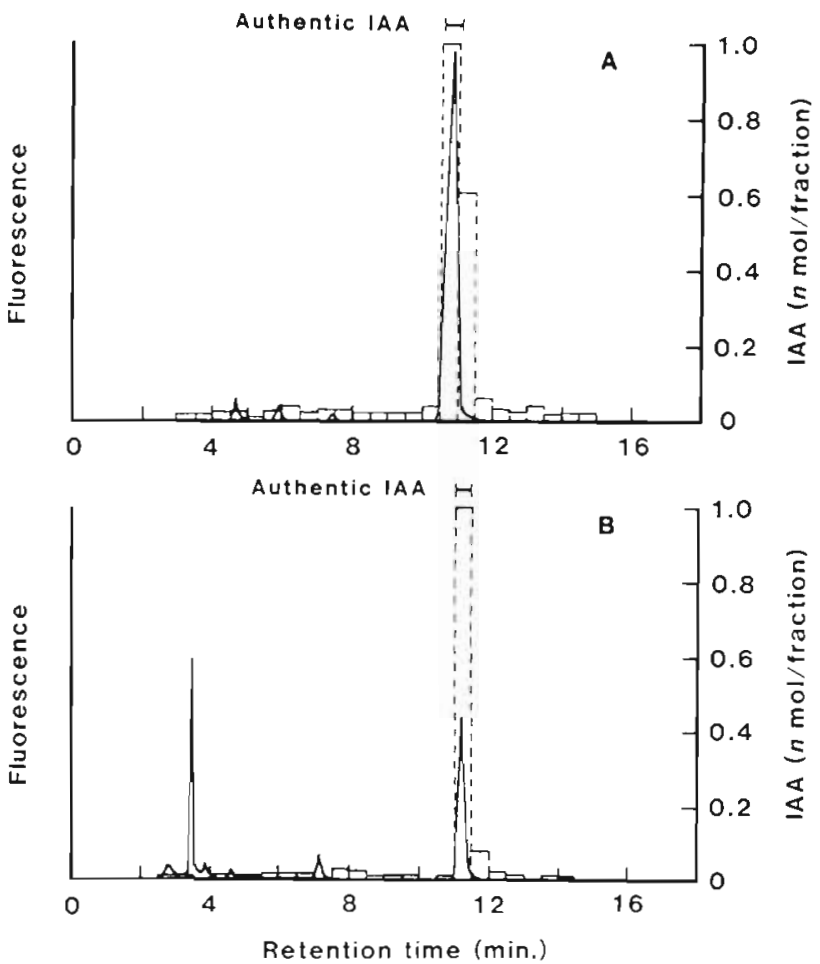

Fig. 2. HPLC separation of the diethylether extract of: (A) centrifuged supernatant of marine sediment collected at Stn T-3 in Tokyo Bay March 1987; (B) Strain 8E-13 culture fluid after incubation for $3 \mathrm{~d}$ in artificial Medium $\mathrm{A}$ enriched with tryptophan. Determination of IAA in fractions made by enzyme immunoassay appeared in the sample chromatogram (Fig. 2A). A methyl ester derivative of this compound also exhibited specific cross-reactivity to the antibody for an authentic IAA methyl ester (m-IAA).

The IAA content of sediment samples tended to fluctuate with both season and location (Table 1). In samples from Aburatsubo Inlet, the IAA content was higher during the summer than in the other seasons: 3.8 to $5.0 \times 10^{-9} \mathrm{~mol} \mathrm{l}^{-1}$ in sediments collected in summer, 0.7 to $2.1 \times 10^{-9} \mathrm{~mol} \mathrm{l}^{-1}$ in sediments of other seasons Significantly more IAA was found in Tokyo Bay than in Aburatsubo sediment samples. In the central region of Tokyo Bay, IAA content was 0.6 to $1.4 \times 10^{-6} \mathrm{~mol} \mathrm{l}^{-1}$ sediment which was over 10 -fold larger than those in the outlet of the same bay and in Sagami Bay. The fine particle content (under $\varnothing 250 \mu \mathrm{m}$ ) in the sediment was measured to clarify possible correlation with the amounts of IAA in sediments. Sediments collected from Tokyo and Sagami Bays were rich in fine sand and mud (over $70 \%$ ) compared with that from Aburatsubo Inlet (30 to $70 \%$ ), which corresponded well with the difference in IAA content between the inlet and bay samples (Fig. 3).

A peak identical to IAA was also detected in the chromatogram of seawater extracts. The IAA content in the seawater was estimated at 1.2 to $22 \times 10^{-11} \mathrm{~mol} \mathrm{l}^{-1}$, which was 1 to 5 orders of magnitude less than that of sediment samples. Although the seasonal and the locational variations of IAA in seawater were not as great as that in sediments, IAA levels tended to be slightly higher in Tokyo Bay than in Aburatsubo Inlet (Table 2).

\section{IAA production of marine bacteria}

IAA production of Strain 8E-13 was examined using the defined medium (A) with and without tryptophan. The IAA produced was clearly identified by HPLCELISA (Fig. 2B). Growth occured to nearly the same extent in both tryptophan-containing and control medium. However, IAA was only produced in the presence of tryptophan. This inducing effect of tryptophan on IAA production was found in all the other marine bacteria isolated previously and in 3 of 4 type-strains (Table 3) tested. Amounts of IAA produced in tryptophan-containing medium were of the order $10^{-7}$ to $10^{-6}$ mol $\mathrm{l}^{-1}$, almost 1 to 2 orders greater than in the control medium.

\section{Evaluation of IAA production in marine sediments}

Fresh sediment samples shaken during incubation yielded a higher IAA content. Similarly, the addition of organic substrates greatly promoted IAA production in 
Table 1. Indole-3-acetic acid (IAA) content (calculated as a unit of total sediment volume, $\left.\times 10^{-9} \mathrm{~mol} \mathrm{l}^{-1}\right)$ in interstitial water of marine sediments

\begin{tabular}{|lccc|}
\hline $\begin{array}{l}\text { Sampling } \\
\text { area }\end{array}$ & $\begin{array}{c}\text { Station } \\
\text { no. }\end{array}$ & Date & $\begin{array}{c}\text { IAA } \\
\text { content }\end{array}$ \\
\hline Aburatsubo Inlet & A-1 & Jan 1985 & 0.7 \\
& & Aug 1985 & 3.8 \\
& & Nov 1985 & 2.1 \\
& A-2 & Nov 1984 & 1.3 \\
& & Jan 1985 & 1.2 \\
& & Aug 1985 & 5.0 \\
Tokyo Bay & Nov 1985 & 1.7 \\
& T-3 & Mar 1987 & 1400 \\
Sagami Bay & T-8 & Mar 1987 & 610 \\
& S-H & Mar 1987 & 88 \\
\hline
\end{tabular}

both the samples (Table 4). The effect of glucose plus tryptophan on IAA production was much greater than that of glucose alone, suggesting that the stimulative effect was mostly induced by tryptophan. The addition of seaweed as a sole substrate also enhanced IAA production (similar to glucose plus tryptophan). In cultures without aeration, IAA accumulation tended to be higher in the water above the sediment than in the interstitial water of the sediment (Table 5). As observed in shaken flasks, organic substrates stimulated IAA production in both sediment samples. The greatest stimulative effect was found in glucose plus tryptophan

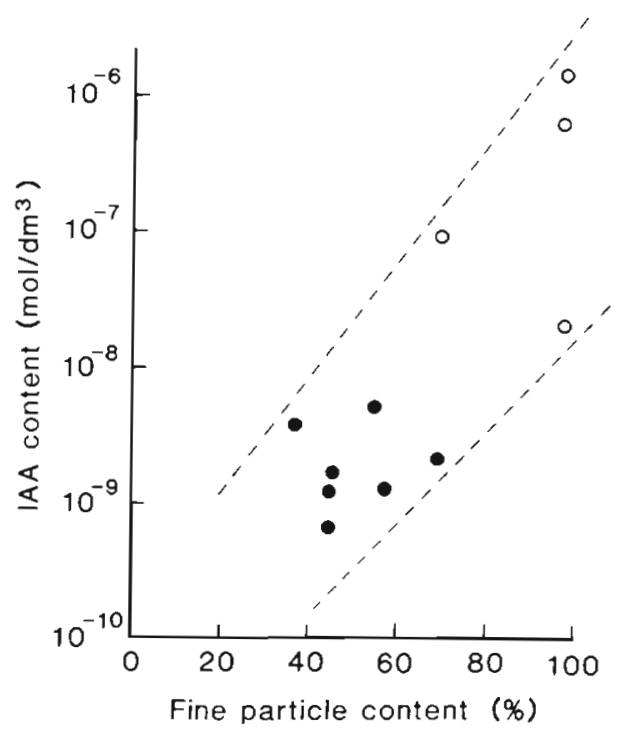

Fig. 3. Relation between IAA content of the interstitial water and fine $(<\varnothing 250 \mu \mathrm{m})$ particle content of marine sediments obtained from Aburatsubo Inlet (•) and from Tokyo and Sagami Bays $(0)$ cultures, the IAA content reaching a maximum of $7.5 \times 10^{-6} \mathrm{~mol} \mathrm{l}^{-1}$ in the water overlying the A-3 sediment. Seaweed substrate enhanced IAA production to the same extent as glucose plus tryptophan even in this condition.

As a whole, greater IAA production (stimulated by enrichment) was found in A-2 sediment samples than in A-3 samples under shaken conditions, while nonshaken A-2 samples were more susceptible to enrichment than A-3 samples. This shows that the extent of IAA production and accumulation in the sediments was influenced not only by the kinds of substrates introduced, but also by the natural activity of the sediments.

\section{DISCUSSION}

The plant hormone auxin, IAA, was detected in marine sediments for the first time. The IAA content of interstitial water from sediments tended to be higher in eutrophicated environments, 0.7 to $5.0 \times 10^{-9} \mathrm{~mol}$ $\mathrm{I}^{-1}$ in the Aburatsubo Inlet and 0.9 to $14 \times 10^{-7} \mathrm{~mol} \mathrm{l} l^{-1}$ in the Tokyo Bay. Since the interstitial water sample for extraction was centrifugally separated from the sediment sample, we assume that the present value represents the amount of free IAA, not tightly absorbed to sediment particles. The amount of IAA in seawater filtrates was almost constant with location at the low level of 1.2 to $22 \times 10^{-11} \mathrm{~mol} \mathrm{l} \mathrm{l}^{-1}$, compared with that in the sediments. The IAA content of seawater filtrates corresponds well with previous estimates of the total auxin content of $1.9 \times 10^{-11} \mathrm{~mol}$ $1^{-1}$ (Bentley 1960).

One possible origin of auxins in natural seawater is algal plants. Previous studies have shown that auxins are present in seaweeds: $5.7 \times 10^{-11} \mathrm{~mol} \mathrm{~g}^{-1}$ fresh wt (Abe et al. 1972), below $5.7 \times 10^{-10} \mathrm{~mol} \mathrm{~g}^{-1}$ fresh wt (Buggeln \& Craigie 1971). Almost the same level of auxin was detected in green alga used here as a bacterial substrate: $1.0 \times 10^{-11} \mathrm{~mol} \mathrm{IAA} g^{-1}$ fresh wt. In

Table 2. IAA content $\left(\times 10^{-11} \mathrm{~mol}^{-1}\right)$ in seawater filtrates

\begin{tabular}{|c|c|c|c|c|}
\hline $\begin{array}{l}\text { Sampling } \\
\text { area }\end{array}$ & $\begin{array}{c}\text { Station } \\
\text { no. }\end{array}$ & $\begin{array}{l}\text { Water } \\
\text { layer }\end{array}$ & Date & $\begin{array}{c}\text { IAA } \\
\text { content }\end{array}$ \\
\hline \multirow{5}{*}{$\begin{array}{l}\text { Aburatsubo } \\
\text { Inlet }\end{array}$} & A- 1 & Surface & Jan 1985 & 1.2 \\
\hline & $A-2$ & Surface & Nov 1984 & 2.3 \\
\hline & & Surface & $\operatorname{Jan} 1985$ & 2.0 \\
\hline & & Surface & Sep 1985 & 2.8 \\
\hline & & Bottom & Sep 1985 & 3.8 \\
\hline \multirow[t]{3}{*}{ Tokyo Bay } & $H$ & Surface & May 1985 & 22 \\
\hline & $\mathrm{T}-3$ & Surface & Mar 1987 & 5.0 \\
\hline & & Bottom & Mar 1987 & 2.8 \\
\hline
\end{tabular}


addition, auxin-like compounds have been detected in unicellular algae (Hussain \& Boney 1971, Grotbeck \& Vance 1972) and in marine phytoplankton samples (Bentley 1958, 1960). Grotbeck \& Vance (1972) estimated the auxin content of Chlorella pyrenoidosa as 3.0 to $8.3 \times 10^{-9} \mathrm{~mol} \mathrm{~g}^{-1}$ dry wt. Although it is not clear whether auxins are released from decaying organisms or from living ones, our results which indicate a much lower IAA concentration in seawater than in sediment suggest that living algae contribute a minor part to the total IAA production of the sea.

Another possible origin of auxin in seawater is marine bacteria. IAA production by marine bacteria was clearly demonstrated in the present study. Amounts of IAA detected in cultures in the late logarithmic growth phase ranged from $10^{-8}$ to $10^{-5} \mathrm{~mol}$ $\mathrm{1}^{-1}$. Tryptophan remarkably enhanced IAA production in almost all samples where it was applied, thus indicating its ability to stimulate IAA production by marine bacteria. Since the inducing effect of tryptophan on IAA-production is known among various terrestrial bacteria - e.g. Agrobacterium tumefaciens (Liu \& Kado 1979), Pseudomonas syringae pv. savastanoi (Hutche- son \& Kosuge 1985), Azotobacter vinelandil (Lee et al. 1970). Azospirillum brasilense (Tien et al. 1979), Rhizobium leguminosarum (Wang et al. 1982), several pseudomonads and xanthomonads (Fett et al. 1987) - it seems that the conversion of tryptophan to IAA is a general function of bacterial communities in the natural environment.

In fresh sediment cultures, tryptophan appeared to stimulate IAA production as well as in the bacterial culture. Since sediment was incubated under dark conditions, our results suggest that there is a great contribution by heterotrophic microorganisms in sediments, rather than by any photosynthetic organisms. While IAA was produced under both aerobic and anaerobic conditions, it is remarkable that when sediment was supplemented with fresh seaweed substrate and incubated anaerobically, greater amounts of IAA. accumulated in the water just above sediments. Since the amount of IAA produced and accumulated in both the overlying water and the interstitial water of sediments was far beyond the original IAA content of seaweed, it is reasonable to suppose that most of the IAA was produced during microbial decomposition of

Table 3. Effect of tryptophan on growth (at $\left.\mathrm{OD}_{600}\right)$ and IAA production $\left(\times 10^{-7} \mathrm{~mol}^{-1}\right.$ ) of marine bacteria. Medium A: free of IAA; $\mathrm{B}$ and $\mathrm{C}$ : originally contained IAA, 0.2 to $0.3 \times 10^{-7} \mathrm{~mol} \mathrm{l}^{-1}$

\begin{tabular}{|c|c|c|c|c|c|c|}
\hline \multirow[t]{2}{*}{ Strain } & \multirow[t]{2}{*}{ Source } & \multirow[t]{2}{*}{ Medium } & \multicolumn{2}{|c|}{ Growth } & \multicolumn{2}{|c|}{ IAA content } \\
\hline & & & Tryp. added & Control & Tryp. added & Control \\
\hline $8 E-13$ & \multirow[t]{3}{*}{ Seawater } & A & 0.32 & 0.33 & 26.3 & $<0.1$ \\
\hline $8 \mathrm{H}-9$ & & A & 0.55 & 0.60 & 2.2 & $<0.1$ \\
\hline $8 I-6$ & & A & 0.19 & 0.18 & 1.6 & $<0.1$ \\
\hline AA -9 & \multirow[t]{3}{*}{ Sediments } & C & 1.69 & 1.68 & 2.4 & 0.9 \\
\hline S1-1 & & $\mathrm{C}$ & 1.22 & 1.25 & 3.4 & 1.3 \\
\hline S1-18 & & $\mathrm{C}$ & 1.22 & 1.24 & 1.6 & 0.8 \\
\hline $\mathrm{KI}-13$ & \multirow[t]{3}{*}{ Seaweeds } & $A$ & 0.51 & 0.43 & 75.4 & 0.1 \\
\hline $\mathrm{KJ}-3$ & & $\mathrm{~B}$ & 0.47 & 0.52 & 15.4 & 1.4 \\
\hline $\mathrm{HO}-13$ & & $\mathrm{C}$ & 1.63 & 1.47 & 13.7 & 2.2 \\
\hline $\mathrm{CC}-16$ & $\begin{array}{l}\text { Unicellular } \\
\text { algal culture }\end{array}$ & $\mathrm{B}$ & 0.78 & 0.77 & 2.1 & 0.3 \\
\hline \multirow{4}{*}{\multicolumn{2}{|c|}{$\begin{array}{l}\text { Aeromonas hydrophila NCMB } 86 \\
\text { Pseudomonas aeruginosa NCMB } 10 \\
\text { Vibrio parahaemolyticus ATCC } 17802 \\
\text { Corynebacterium sp. }{ }^{\text {. }}\end{array}$}} & $\mathrm{C}$ & 1.12 & 1.08 & 15.7 & 3.8 \\
\hline & & $\mathrm{C}$ & 1.23 & 1.23 & 4.3 & 1.1 \\
\hline & & $\mathrm{C}$ & 1.65 & 1.68 & 24.0 & 3.3 \\
\hline & & $\mathrm{C}$ & 1.54 & 1.42 & 1.4 & 1.8 \\
\hline
\end{tabular}

Table 4. IAA content in centrifuged supernatant of the sediment-ASW medium mixture after incubation in aerating condition in the dark. Values are IAA content $\left(\times 10^{-9} \mathrm{~mol} \mathrm{l}^{-1}\right)$. Seaweed: per $10 \mathrm{~g}$ fresh wt Ulva sp. originally contained IAA at $0.1 \times 10^{-9} \mathrm{~mol}$

\begin{tabular}{|c|c|c|c|c|c|}
\hline \multirow{2}{*}{$\begin{array}{l}\text { Sediment } \\
\text { source }\end{array}$} & \multirow[t]{2}{*}{ Pre-incubation } & \multicolumn{4}{|c|}{ Substrate enriched to the ASW medium } \\
\hline & & None & Glucose & Glucose+Tryptophan & Seaweed \\
\hline$A-2$ & $<0.1$ & 26.0 & 44.5 & 271.0 & 278.0 \\
\hline A-3 & $<0.1$ & 21.5 & 56.0 & 148.0 & 118.0 \\
\hline
\end{tabular}


Table 5. IAA content in the interstitial water of the sediment (sediment) and in the water overlying the sediment (water) after incubating without aeration under the dark. Values are IAA content $\left(\times 10^{-9} \mathrm{~mol}^{-1}\right)$

\begin{tabular}{|c|c|c|c|c|c|c|}
\hline \multirow{2}{*}{$\begin{array}{l}\text { Sediment } \\
\text { source }\end{array}$} & \multirow[t]{2}{*}{ Sample } & \multirow[t]{2}{*}{ Pre-incubation } & \multicolumn{4}{|c|}{ Substrate enriched to the ASW medium } \\
\hline & & & None & Glucose & Glucose+Tryptophan & Seaweed \\
\hline \multirow[t]{2}{*}{ A-2 } & Water & $<0.1$ & 13.0 & 39.0 & 525.0 & 134.0 \\
\hline & Sediment & $<0.1$ & 1.5 & 2.5 & 83.5 & 3.5 \\
\hline \multirow[t]{2}{*}{$A-3$} & Water & $<0.1$ & 10.5 & 73.5 & 7540.0 & 255.0 \\
\hline & Sediment & 0.1 & 2.5 & 6.0 & 566.0 & 682.0 \\
\hline
\end{tabular}

seaweed. Therefore, it seems that the settlement of a large amount of organic debris, as a result of active primary production, induces IAA production and accumulation in stagnant near-bottom water. Although there is little data on the vertical distribution of IAA in seawater, we found higher IAA concentrations in the bottom-water than in the surface-water of Aburatsubo Inlet. In addition, higher cytokinin activity has been detected (another plant hormone group of bacterial origin in the sea; Maruyama et al. 1986) in estuary near-bottom water than in surface water over $1 \mathrm{yr}$ (Kentzer et al. 1980).

In general, algal growth is enhanced by supplements of extracts of terrestrial soil, suggesting the presence of certain biologically active compounds in the soil (Provasoli et al. 1957). Marine sediments also contain growth-promoting compounds for unicellular algae, especially for red-tide flagellates (Iwasaki 1979, Takahashi \& Fukazawa 1982). These compounds may be released from the bottom sediments under lowoxygen conditions, together with some nutrients, organic chelators and vitamins (Iwasaki 1979, Fukazawa et al. 1980). Although the exact chemical nature of the compounds which stimulate growth of red-tide flagellates is still obscure, our results suggests that auxin, IAA, may be one such active compound in marine sediments.

A previous study on the multicellular green alga Caulerpa sertularioides indicated that its long-term thallus growth could be attained, not only in the presence of an auxin IAA, but also in the presence of marine-sand rich in microorganisms (Mishra \& Kefford 1969). This finding is comparable with our results, that marine sediments contain IAA and IAA producing microorganisms. Dawes (1971) also observed the stimulative effects of IAA on thallus proliferation of the green alga $C$. prolifera, at a concentrations of 1 to $5 \times 10^{-6} \mathrm{~mol} \mathrm{l}^{-1}$, whereas at concentrations beyond $10^{-5}$ mol $l^{-1}$ growth was inhibited. Although the level of IAA reported for green algae was slightly higher than the range of IAA concentration in marine sediments examined in this study, it is possible that further IAA production by sediment microorganisms affects growth. In addition, Harrison (1978) showed that mi- crobial decay of eelgrass promoted growth of the green alga Ulva fenestrata, suggesting that certain compounds, released by bacterial activity, affect growth. Further studies on algal growth regulators in marine environments are necessary to elucidate, not only the growth of multicellular algae but also the formation of red tides in the sea.

Acknowledgements. This research was supported by grants for Scientific Research from the Ministry of Education, Science and Culture, Japan (No. 62560 205). We express our gratitude to Dr I. Yamaguchi, Faculty of Agriculture, University of Tokyo, for his helpful advice on the IAA analysis, and to Dr G. R. Brown, University of Toronto, Canada, for correcting our English. Thanks are also due to officers and crew members of the RV 'Tansei-maru' and to staff of the Misaki marine biological station

\section{LITERATURE CITED}

Abe, H., Uchiyama, M., Sato, R. (1972). Isolation and identification of native auxins in marine algae. Agric. biol. Chem. 36: 2259-2260

Bentley, J. A. (1958). Role of plant hormones in algal metabolism and ecology. Nature, Lond. 181: 1499-1502

Bentley, J. A. (1960). Plant hormones in marine phytoplankton, zooplankton and seawater. J. mar. biol. Ass. U.K. 39: $433-444$

Buggeln, R. G., Craigie, J. S. (1971). Evaluation of evidence for the presence of indole-3-acetic acid in marine algae. Planta 97: 173-178

Dawes, C. J. (1971). Indole-3-acetic acid in the green algal coenocyte Caulerpa prolifera (Chlorophyceae, Siphonales). Phycologia 10: 375-379

Fett, W. F., Osman, S. F. Dunn, M. F. (1987). Auxin production by plant-pathogenic pseudomonads and xanthomonads. Appl. environ. Microbiol. 53: 1839-1845

Fukazawa, N., Ishimaru, T., Takahashi, M., Fujita, Y (1980). A mechanism of 'red tide' formation. I. Growth rate estimate by DCMU-induced fluorescence increase. Mar Ecol. Prog. Ser 3: $217-222$

Grotbeck, L., Vance, B. D. (1972). Endogenous levels of indole-3-acetic acid in synchronous cultures of Chlorella pyrenoidosa. J. Phycol. 8: 272-275

Harrison, P. G. (1978). Growth of Ulva fenestrata (Chlorophyta) in microcosms rich in Zostera marina (Anthophyta) detritus. J. Phycol 14: 100-103

Hofman, P. J, Featonby-Smith, B. C., van Staden, J. (1986). The development of ELISA and RIA for cytokinin estimation and their application to a study of lunar periodicity in 
Ecklonia maxima (Osbeck) Papenf. J. Pl. Physiol. 122: $455-466$

Hussain, A., Boney, A. D. (1969). Isolation of kinin-like substances from Laminaria digitata. Nature, Lond. 223: 504-505

Hutcheson, S. W., Kosuge, T (1985). Regulation of 3 indoleacetic acid production in Pseudomonas syringae pv. savastanoi. Purification and properties of tryprophan 2monooxygenase. J. biol. Chem. 260: 6281-6287

Iwasaki, H. (1979). Physiological ecology of red tide flagellates. In: Levandowsky, M., Hutner, S. H. (eds.) Biochemistry and physiology of Protozoa, Vol. 1. Academic Press, New York, p. 357-393

Kentzer, T., Synak, R., Burkiewicz, K., Banas, A. (1980) Cytokinin-like activity in sea water and Fucus vesiculosus L. Biol. Plant. (Prague) 22: 218-225

Lee, M., Breckenridge, C., Knowles, R. (1970). Effect of some culture conditions on the production of indole-3-acetic acid and a gibberellin-like substance by Azotobacter vinelandii. Can. J. Microbiol. 16: 1325-1330

Liu, S.-T., Kado, C. I. (1979). Indoleacetic acid production: a plasmid function of Agrobacterium tumefaciens C58. Biochem. biophys. Res. Commun. 90: 171-178

Maruyama, A., Maeda, M., Simidu, U. (1986). Occurrence of plant hormone (cytokinin)-producing bacteria in the sea. $J$. appl. Bact. 61: 569-574

Maruyama, A., Yamaguchi, I., Maeda, M., Simidu, U. (1988). Evidence of cytokinin production by a marine bacterium and its taxonomic characteristics. Can. J. Microbiol. 34:829-833

Mertens, R., Eberle, J., Arnscheidt, A., Ledebur, A., Weiler, E W. (1985). Monoclonal antibodies to plant growth regulators. II. Indole-3-acetic acid. Planta 166: 389-393

Mishra, A. K., Kefford, N. P. (1969). Developmental studies on the coenocytic alga, Caulerpa sertularioides. J. Phycol. 5 . 103-109

This article was presented by Professor G. Rheinheiner, Kiel, F.R. Germany
Mooney, P. A., van Staden, J. (1987). Tentative identification of cytokinins in Sargassum heterophyllum (Phaeophyceae). Botanica mar. 30: 323-325

Pedersén, M. (1973). Identification of a cytokinin, 6-(3-methyl2-butenylamino)purine, in sea water and the effect of cytokinins on brown algae. Physiologia Pl. 28: 101-105

Pedersén, M., Fridborg, G. (1972). Cytokinin-like activity in sea water from the Fucus-Ascophyllum zone. Experientia 28: $111-112$

Provasoli, L., McLaughlin, J. J. A., Droop, M. R. (1957). The development of artificial media for marine algae. Arch. Mikrobiol. 25: 392-428

Schlenk, H., Gellerman, J. L. (1960). Esterification on fatty acids with diazomethane on a small scale. Analyt. Chem. 32: $1412-1414$

Takahashi, M., Fukazawa, N. (1982). A mechanism of 'redtide' formation II. Effect of selective nutrient stimulation on the growth of different phytoplankton species in natural water. Mar. Biol. 70: 267-273

Tay, S. A. B., MacLeod, J. K. Palni, L. M. S., Letham, D. S. (1985). Detection of cytokinins in a seaweed extract. Phytochem. 24: 2611-2614

Tay, S. A. B., Palni, L. M. S., MacLeod, J. K. (1987). Identification of cytokinin glucosides in a seaweed extract. J. Plant Growth Regul. 5: 133-138

Tien, T M., Gaskins, M. H., Hubbell, D. H. (1979). Plant growth substances produced by Azospirillum brasilense and their effect on the growth of pearl millet (Pennisetum americanum L.). Appl. environ. Microbiol. 37: 1016-1024

Wang, T L., Wood, E. A., Brewin, N. J. (1982). Growth regulators, Rhizobium and nodulation in peas. Indole-3-acetic acid from the culture medium of nodulating and nonnodulating strains of $R$. leguminosarum. Planta 155: 345-349

Manuscript first received: February 10, 1989

Revised version accepted: August 11, 1989 